\title{
Birna Arnbjörnsdóttir*
}

\author{
University of Iceland, Iceland \\ birnaarn@hi.is
}

\section{Patricia Prinz}
Mercy College, New York, New York, USA
pprinz@mercy.edu

\section{FROM EFL TO EMI: DEVELOPING WRITING SKILLS FOR THE HUMANITIES}

\section{Abstract}

This paper presents a study of a program designed to address challenges in writing English for Specific Academic Purposes (ESAP) (Dearden, 2015; Flowerdew, 2016) at the University of Iceland, where EMI programs continue to expand appreciably. Nordic and international exchange students enrolled in EMI humanities programs are fluent in conversational English and informal writing but lack disciplinespecific writing competencies for tertiary study in English. A program which operationalizes targeted core writing competencies was developed to improve writing in a single semester. The program design drew on research investigating the needs of competent L1 writers (Lavelle \& Guarino, 2003) and of L2 writers in the Nordic countries (Arnbjörnsdóttir \& Ingvarsdóttir, 2015; Hellekjær, 2009). Based on pre- and post-surveys and students' reflections, this study examines the extent to which the new academic writing approach and curriculum met the semester goals of transitioning students to thesis-driven writing and developing a sense of autonomy for future writing assignments. The pre-study revealed that 10 years of EFL writing instruction developed students' awareness of the principles of academic writing, yet they failed to apply them when writing in the disciplines. The post- data analysis and reflections revealed increased genre awareness, greater writer efficacy and autonomy, and improved academic writing.

\section{Key words}

L2 academic writing, EMI, ESAP, humanities.

* Corresponding address: Birna Arnbjörnsdóttir, Saemundargata 2, 101 Reykjavík, Iceland. 


\section{Sažetak}

Ovaj rad se bavi kursom osmišljenim radi prevazilaženja problema u pisanju na engleskom za specifične akademske potrebe (Dearden, 2015; Flowerdew, 2016) na Univerzitetu u Islandu gde su sve brojniji programi nastave na engleskom jeziku. Studenti iz nordijskih zemalja i studenti na međunarodnoj razmeni upisani na fakultete humanističkog usmerenja sa nastavom na engleskom jeziku fluentni su u razgovornom engleskom i neformalnom pisanju, ali im nedostaje sposobnost pisanja tekstova na engleskom svojstvenih naučnoj disciplini koju studiraju. Osmišljen je jednosemestralni kurs razvoja ciljanih ključnih kompetencija radi poboljšanja veštine pisanja, zasnovan na istraživanjima koja se bave potrebama kompetentnih pisaca na maternjem jeziku (Lavelle \& Guarino, 2003) i na engleskom kao drugom jeziku u nordijskim zemljama (Arnbjörnsdóttir \& Ingvarsdóttir, 2015; Hellekjær, 2009). Na osnovu podataka dobijenih putem anketa sprovedenih pre i nakon završenog kursa i na osnovu studentskih stavova, ova studija istražuje u kojoj meri je novi pristup akademskom pisanju ostvario ciljeve semestra u pogledu osposobljavanja studenata za pisanje u cilju razvijanja teza, kao i njihove veće autonomije u pisanju radova u budućnosti. Anketa sprovedena pre početka kursa otkrila je da je desetogodišnja nastava pisanja na engleskom jeziku razvila svest studenata o principima akademskog pisanja, ali i njihovu nesposobnost da ih primene na pisanje unutar svoje naučne discipline. Anketa sprovedena nakon završenog kursa i studentski stavovi ukazali su na povećanu žanrovsku svest, veću autonomiju i efikasnost u pisanju, kao i na poboljšanje akademskog pisanja.

\section{Ključne reči}

akademsko pisanje na engleskom, nastava na engleskom jeziku, engleski za specifične akademske potrebe, humanističke nauke.

\section{INTRODUCTION}

The spread of English as an international language has led to a surge in programs that use English as a Medium of Instruction (EMI). The rapid shift to teaching academic subjects through English in countries where English is not the first language has been characterized as a "global phenomenon" by the British Council and is likely to continue (Dearden, 2015). Unlike EFL programs, EMI programs have a high threshold of English proficiency to enter and do not provide English language instruction or support (Coleman, 2006; Dearden, 2015). 
As institutions pressure faculty and students toward teaching and learning through English, a growing number of students and faculty lack necessary preparation to use academic English effectively (Dimova, Hultgren, \& Jensen, 2015). A British Council study of 55 tertiary institutions worldwide found that the majority of respondents from public and private institutions report concerns about proper implementation of EMI programs due to a lack of resources. Specifically, the study noted a lack of "sufficiently trained teachers, materials and assessment" (Dearden, 2015: 22-23).

The fastest growth of internationalization at the tertiary level has been in Northern Europe, especially the Nordic countries, where EMI programs have proliferated (Wächter \& Maiworm, 2015). Nordic university policies presuppose that Nordic students are sufficiently prepared for study in English at their home universities and for many institutions, EMI program growth is an explicit goal (Hultgren, Gregersen, \& Thøgersen, 2014). However, multiple studies report that Nordic students find using English at university problematic (Arnbjörnsdóttir \& Ingvarsdóttir, 2015; Hellekjær, 2005, 2009; Pecorari, Shaw, Irvine, \& Malmström, 2011; Pecorari, Shaw, Irvine, Malmström, \& Mežek, 2012).

Research on effective instruction for EMI students has not kept pace with the rapid worldwide expansion of programs. Of particular concern is the identified gap in research on effective approaches and materials to support EMI students (Dearden, 2015). In the Nordic countries, research has documented the range of challenges encountered by EMI students whose conversational fluency masks their lack of academic English proficiency. These studies will be reviewed in the next section.

No study is available that reports interventions designed specifically for EMI students in the Nordic countries. The current study attempts to address the gap by examining the effectiveness of a new academic writing program that uses an approach and textbook developed expressly to meet the unique needs of EMI learners. The new program draws on both L1 and L2 academic writing research and was designed to make significant improvements in EMI students' academic writing in a semester. This article presents: 1) the program description and theoretical foundation; and 2) findings that indicate the success of that program in meeting its goals.

\section{TRANSITIONING TO ENGLISH IN EMI PROGRAMS: CHALLENGES FOR STUDENTS}

Research related to EMI conversion at international universities has begun to define issues with respect to learning outcomes in the disciplines and English instruction. In a review of European studies of students learning through English at local universities, Coleman's analysis (2006) revealed inadequate English skills among faculty and students and the need for instructor training in content delivery 
through a foreign language. Secru (2004 as cited in Coleman, 2006) claims that English language use diminishes the quality of teaching and learning while increasing student and faculty workloads. Similarly, research at Dutch universities suggests lower student achievement in English-medium courses compared to native-language courses (Coleman, 2006; Vinke, Snippe, \& Hoechems, 1998).

Nordic researchers report challenges similar to these European universities. Hellekjær and Westergaard's (2003: 1) Norwegian study concludes that the "effectiveness of English-medium content teaching is influenced by language problems, in that language seems to constrain teaching and instructional methods." Studies also report that EMI may cause students and instructors to be less expressive in class (Hellekjær, 2005; Wilkinson, 2005). In recent studies on the effects of using English for academic purposes at the University of Iceland, more than a third of students report struggling with English; similarly, students indicate that the use of multiple strategies to access text content in English increases workloads (Arnbjörnsdóttir \& Ingvarsdóttir, 2010, 2017; Dimova et al., 2015).

There is a growing recognition in the Nordic countries that traditional primary and secondary EFL programs fail to prepare students for the academic language and literacy required for tertiary study in English in the disciplines. Hellekjær's pioneering studies $(2005,2009)$ found Norwegian secondary students lack proficiency in English academic vocabulary and text comprehension. Hellekjær (2008: 15) concluded that "Norwegian complacency about the quality of upper secondary English as a foreign language (EFL) instruction as preparation for higher education [...] is unmerited". Researchers from Finland (Pilkinton-Pihko, 2010), Norway (Ljösland, 2008), Sweden (Pecorari et al., 2012), and Denmark (Swerts \& Westbrook, 2013) report similar findings.

Icelandic studies (Arnbjörnsdóttir \& Ingvarsdóttir, 2017; Jeeves, 2013) reveal that Icelandic and Northern European undergraduates struggle in EMI humanities programs notwithstanding conversational English fluency acquired extramurally and reinforced in primary and secondary EFL instruction. Despite conversational English proficiency and extensive (often 10 years) prior English instruction, University of Iceland undergraduates arrive underprepared for academic reading and writing in EMI programs. English academic writing emerges as one of the greatest challenges (Arnbjörnsdóttir \& Ingvarsdóttir, 2015; Hellekjær \& Westergaard, 2003).

\section{ACADEMIC WRITING IN EMI: THEORETICAL BACKGROUND FOR A NEW APPROACH AND TEXTBOOK}

Student course evaluations, instructor feedback and attrition, and faculty dissatisfaction with students' writing performance at the University of Iceland suggested that traditional EFL instruction was inadequate preparation for 
academic writing tasks in the humanities programs. Consistent with L2 research suggesting that "learning to write in a different language is not just a matter of developing more fluent linguistic skills" (Galbraith, 2009: 20), the University sought a new pedagogical approach and textbook which would build on EMI students' English linguistic proficiency and engage them in the cognitive processes required for effective academic writing. An extensive search did not result in a suitable textbook that focused on the cognitive processes associated with deeper level writing approaches. Therefore, a new program textbook, The Art and Architecture of Academic Writing (AAAW), was developed.

The AAAW textbook draws on L1 research which defines deep-level qualities associated with competent writers (Lavelle \& Zuecherer, 2001; Lavelle \& Guarino, 2003) including thesis-driven focus, meaning making, audience, hierarchical organization, revision, and metacognitive reflection. This orientation is a departure from surface-level EFL writing approaches based on the reproduction of discourse patterns, linear presentation of data, and editing.

To effect change in a single semester and maintain focus on deeper processes, the textbook is tightly organized around three interwoven strands: 1) a pedagogical approach that targets writer autonomy; 2) the active development of writer self-efficacy; and 3) strategies for thesis-driven writing. The purpose of this study is to gauge the extent to which this approach and the textbook foster awareness of the deeper-level features of humanities-based, thesis-driven writing and assess students' perceptions of their ability to execute thesis-driven writing assignments. The next section describes the underlying principles of the program and provides a theoretical rationale for each component.

\subsection{Pedagogical approach - towards writer autonomy}

The concept of autonomy in language learning centers on the individual's ability to take charge of his or her own learning process (Holec, 1981). The ability to use a repertoire of effective academic writing strategies plays a key role in developing autonomous writers who plan and execute their own writing processes and products (O'Malley \& Chamot, 1990; Oxford, 1990). The AAAW approach fosters both the psychological dimensions of "self-evaluation, organization, goal-setting, planning, information-seeking, record-keeping, and self-monitoring" (Oxford, 2003: 84) and the sociocultural dimensions of "the mediated learner, the cognitively apprenticed learner [...] and the self-efficacious learner" (Oxford, 2015: 63).

The psychological perspective on autonomy reflects cognitive models of L1 writing which recognize strategies as precursors to functional writing skills (Deane, Odendahl, Quinlan, Fowles, Welsh, \& Bivens-Tatum, 2008; Galbraith, 2009). The program seeks to transform EMI learners' existing conceptual knowledge of academic writing into functional writing strategies through an 
explicit approach. Cognitive load, the total amount of mental effort used in the working memory, influences the writer's ability to learn new strategies (Galbraith, 2009). Therefore, all aspects of the curriculum are highly scaffolded and recursive to reduce cognitive load and lead students toward self-regulation. The AAAW text focuses on developing autonomy in the use of a single component or strategy at a time. As a new component is mastered, it is synthesized into a more complex writing task. For example, students engage in intensive practice using evidence to support a topic sentence in a paragraph. Once they master the paragraph, they focus on organizing paragraphs hierarchically to support a thesis. Introductions and conclusions are mastered as separate units. Students gradually synthesize introductions, body paragraphs, and conclusions into full essays.

The AAAW text uses an explicit instructional approach (Archer \& Hughes, 2011; Brown, Collins, \& Duguid, 1989) based on a cognitive apprenticeship model. The textbook mediates learning through predictable sequences of scaffolded learning activities beginning with an explanation of purpose and rationale, followed by modeling, guided learning practice, and culminating in a gradual release of responsibility and the learner's independent production of the targeted task. Extensive studies of L1 elementary and secondary school writers have demonstrated that explicit instruction has large effects on writing quality (Graham \& Perin, 2007; Graham, Harris, \& McKeown, 2013). Research with L1 college writers (MacArthur, Philippakos, \& Ianetta, 2015) and L2 college writers (SegevMiller, 2004) reports similar positive effects.

The explicit, concise, and scaffolded structure of AAAW incorporates visual presentation of the material, minimizing the time students are engaged in reading. The format of each chapter uses the following predictable sequence of presentation and practice to foster the psychological and sociocultural dimensions of autonomy for writing:

a) Relevance: guides students to examine the purpose of the content and its relationship to effective academic writing;

b) Practice: models writing elements explicitly through demonstration and provides structured practice to help students master the element;

c) Production: shows students how to incorporate the mastered element in a specific genre beginning with a series of short scaffolded assignments and leading to independent writing at the end of each chapter;

d) Reflection: fosters the development of metacognitive awareness by asking students to respond to questions and prompts on topics in the program.

\subsection{Developing the writer - self-efficacy}

Self-efficacy, an individual's belief about his or her ability to accomplish a task (Bandura, 1977), exerts a mediating influence on the writer's motivation and 
confidence. Experience with task performance or mastery influence self-efficacy perceptions. In a review of research studies Pajares (2003) found a predictive link between writing self-efficacy and writing performance.

Metacognitive awareness is a prerequisite for developing perceptions of selfefficacy and autonomy. To foster writers' perceptions of self-efficacy and autonomy, the textbook actively engages students in metacognitive reflection. When a new rhetorical feature or process is introduced, its role and importance is highlighted in a "Relevance" text box. As the lesson unfolds, a "Reflection" text box prompts students to think critically about their understanding of the function and value of the topic. For example, students reflect on their own experience with thesis statements as readers. In a later section, students reflect critically on the role of thesis statements in their own writing processes. Reflections submitted through an electronic journal serve as the basis for students' final meta-reflection on changes in the beliefs, self-regulation, and processes that guide their writing.

\subsection{Content - thesis-driven writing in the humanities}

The concept of thesis-driven writing, which organizes and presents information to establish the validity of a thesis statement, undergirds virtually all of the content and processes. The text builds on students' pre-existing genre knowledge as a foundation for a deeper exploration of thesis-driven writing. The text uses three genres - the essay, the case study, and the research paper - as lenses for examining deeper level features of writing discussed above (thesis-driven focus, meaning, audience, hierarchical organization, revision, and metacognitive reflection).

The essay is a foundation of writing in the humanities. The AAAW text examines four essay genres, each of which serves as a medium for understanding and developing specific deeper level processes. Description, narrative, enumeration, and compare/contrast were selected based on their familiarity to students. Narrative and description are examined in their role as evidence to support a thesis statement rather than as expressive or literary genres. In addition to reinforcing thesis-driven writing, these genres prepare students for using narrative and description as evidence in the case study they will conduct later in the course.

Expository discourse correlates with patterns used to organize knowledge and relates to the cognitive operations that reflect deeper level thinking (Deane et al., 2008). Through enumeration and compare/contrast genres, students examine and practice writing thesis statements, evidence, hierarchical organization, and cohesion in expository writing assignments. The AAAW textbook avoids assignments in which students rely on secondary sources until the end of the course. Instead, assignments support students' meaning-making processes by asking students to draw on their personal knowledge and experience as evidence to support a thesis statement. For example, when examining compare/contrast 
exposition, students read and analyze a short description of ancient Roman marriage customs. Students write an essay which compares ancient and contemporary marriage using their own knowledge of modern marriage to support the thesis.

The case study genre of academic writing (Gardner \& Nesi, 2013) asks students to conduct primary research, organize and analyze information, and create a thesis statement based on the primary data they have collected. The case study assignment prepares students for the increasing use of Case Based Learning (CBL) in various disciplines (Hall, Magee, \& Clapp, 2016). Students develop a deeper awareness of thesis-driven writing and learn skills in citation, paraphrase, summary, and so on as they use primary sources such as interviews, original documents, and observations as evidence. The case study plays a recursive role in the curriculum as students apply previously mastered skills in the hierarchical presentation of ideas, meaning, and coherence in a new context.

The course culminates in a final writing project in which students expand the case study into a full research paper. Students use secondary sources to create the sociohistorical context for their case studies. The assignment synthesizes the knowledge and skills students developed through essays, primary research, and secondary research. The following sections present three facets of a study on students' experiences with the AAAW approach and textbook: thesis-driven writing, writer self-efficacy, and writer autonomy.

\section{THE STUDY}

The mixed-method study reported here examines the extent to which the new academic writing program achieved the objectives of transitioning EMI humanities students to thesis-driven writing approaches and developing personal perceptions of writer autonomy and writer self-efficacy. Below, the mixed method approach (Creswell, 2013) is described. First, pre- and post-course surveys provide an overview of possible changes in students' perceptions related to their writing proficiency, autonomy, and self-efficacy as writers. Then students' reflections offer a more in-depth understanding of their views of thesis-driven writing. All data were collected during the same semester in the spring of 2013.

\subsection{Participants}

The participants were first-year University of Iceland students enrolled in a onesemester intensive academic writing course in the BA program in English Language and Linguistics in the School of Humanities. The writing course was designed for English Linguistics or Literature majors or minors and requires incoming students to have near-native English proficiency because no remedial 
English courses are offered. However, students from a variety of other humanities disciplines and international exchange students enrolled in the course believing it would improve their general academic English. As a result, the participants were from mixed L2 backgrounds although the majority were Icelandic speakers.

One hundred and eleven students submitted their reflections about thesisdriven writing as part of the course requirements. Of these, ninety-one participants completed both the pre- and post-course surveys. Twenty-one males and 70 females participated in the survey, which is roughly the same ratio of men and women in the population registered at the University. Over $60 \%(\mathrm{~N}=54)$ of the participants in the surveys were younger than 25 (normal age of university students in the Nordic country being 21-24), a third were between the ages of 26$40(\mathrm{~N}=31)$ while $7 \%(\mathrm{~N}=6)$ were older than 40 years. Ninety percent of the students had started learning English before the age of 12 and almost half $(46 \%)$ had received formal English instruction for 9-12 years. The students expressed high confidence in their English skills, especially their receptive skills, as almost 90\% reported that their listening and reading skills were good or very good. Productive skills, speaking and writing, were rated somewhat lower.

\subsection{Instruments}

\subsubsection{Pre- and post-surveys}

The participants completed identical pre- and post-course surveys, each with 36 questions (see Appendix). Sixteen questions elicited background information including gender, age, English instruction, and English experience. Four questions were asked about general English proficiency. Another sixteen questions focused on students' pre- and post-course perceptions of themselves as writers. Eleven of these 16 questions were adapted from the Inventory of Processes in College Composition (IPIC) developed by Lavelle and Zuercher (2001). Only the questions concerning writer self-efficacy, autonomy, and English writing proficiency are addressed in this paper.

\subsubsection{Reflections}

The 111 participants in the reflection data set were students in the same first-year writing course in an English Linguistics and Literature program. The course requirements included responding to writing prompts embedded throughout the text that guided students' personal reflections on the course content. One assignment was a reflection on the purpose of a working thesis, a tentative statement that guides the research or review until a full thesis can be developed. 
The prompt was: 'The purpose of a working thesis. Think about a time when you started to write a paper without really knowing what you were going to write about. How did that work?' Students then wrote 1-2 paragraphs reflecting on the ideas expressed in the prompt.

\subsubsection{Methods of analysis}

The survey responses were analyzed using simple percentage and correlation calculations through SPSS. The reflections were analyzed using an interpretive analysis based on a Grounded Theory approach to identify general themes (Creswell, 2013; Smith, Flowers, \& Larkin, 2009). Analysis of the surveys is presented below followed by the thematic analysis of the reflections.

\section{RESULTS}

\subsection{Pre- and post-course surveys}

The results of the pre- and post- surveys are based on simple percentages of responses on a five-point Likert scale. The 16 questions that asked specifically about improvements in perceptions of autonomy, efficacy, and writing research papers are included in the analysis below.

\subsubsection{Survey analysis by theme: Autonomy}

The autonomy-related questions are designed to measure students' perceptions of their ability to control their own writing (Oxford, 2015). Four questions related to writer autonomy (Q 17, 30, 24, and 28) focused on improvement in writing. These items are displayed in Table 1.

The results show an overall modest rise in autonomy as students reported increased knowledge of the elements of academic writing and ability to write on their own without assistance.

The percentage of participants who agreed or strongly agreed with the statement "I can write a research paper without any help or instruction" (Q17) increased by 13 percentage points in the post-course survey. The percentage of students who neither agreed nor disagreed decreased by 7 percentage points. The students who responded that they disagreed that they can write research papers without help decreased by 6 percentage points. This is a concern that will be addressed in the discussion section. 


\begin{tabular}{|c|l|c|c|c|c|c|c|}
$\begin{array}{c}\text { QuESTION } \\
\text { NO. }\end{array}$ & \multicolumn{1}{|c|}{ QUESTIONS } & \multicolumn{2}{|c|}{$\begin{array}{c}\text { AGREE OR } \\
\text { STRONGLY AGREE }\end{array}$} & \multicolumn{2}{|c|}{$\begin{array}{c}\text { DISAGREE OR } \\
\text { STRONGLY } \\
\text { DISAGREE }\end{array}$} & \multicolumn{2}{c|}{$\begin{array}{c}\text { NEITHER AGREE } \\
\text { NOR DISAGREE }\end{array}$} \\
\hline $\mathbf{1 7}$ & $\begin{array}{l}\text { I can write a research paper without } \\
\text { any help or instruction. }\end{array}$ & $19 \%$ & $32 \%$ & $59 \%$ & $53 \%$ & $22 \%$ & $15 \%$ \\
\hline $\mathbf{3 0}$ & $\begin{array}{l}\text { I am familiar with the components of a } \\
\text { research paper. }\end{array}$ & $62 \%$ & $86 \%$ & $15 \%$ & $7 \%$ & $23 \%$ & $8 \%$ \\
\hline $\mathbf{2 4}$ & $\begin{array}{l}\text { I do well on tests requiring essay } \\
\text { answers. }\end{array}$ & $60 \%$ & $62 \%$ & $11 \%$ & $14 \%$ & $29 \%$ & $24 \%$ \\
\hline $\mathbf{2 8}$ & $\begin{array}{l}\text { I cannot revise my written work } \\
\text { because I cannot see my own } \\
\text { mistakes. }\end{array}$ & $23 \%$ & $27 \%$ & $53 \%$ & $58 \%$ & $24 \%$ & $15 \%$ \\
\hline
\end{tabular}

$(N=91)$

Table 1. Writer autonomy

It is worth noting that the number of those who agreed with the statement "I am familiar with the components of a research paper" (Q30) increased by 24 percentage points from the pre- survey to the post- survey. Generally, students seemed to be more aware of their writing abilities in the post- survey as fewer students responded with ambivalence ('neither agree nor disagree') after the course.

\subsubsection{Survey analysis by theme: Self-efficacy for writing}

Questions designed to measure changes in students' perceptions of writer efficacy relate to how their beliefs about enabling factors, such as thoughts, feelings, and actions, affect their ability to accomplish the writing task successfully (Pajares, 2003). In the post-course surveys, students reported lower anxiety about their ability and lower concerns about having their writing evaluated than at the start of the writing task. Expectations for good grades remain relatively unchanged. The results are shown in Table 2.

\begin{tabular}{|c|c|c|c|c|c|c|c|}
\hline $\begin{array}{c}\text { QUESTION } \\
\text { NO. }\end{array}$ & \multicolumn{2}{|c|}{ QUESTIONS } & \multicolumn{2}{|c|}{$\begin{array}{c}\text { AGREE OR } \\
\text { STRONGLY AGREE }\end{array}$} & \multicolumn{2}{|c|}{$\begin{array}{c}\text { DISAGREE OR } \\
\text { STRONGLY } \\
\text { DISAGREE }\end{array}$} & \multicolumn{2}{c|}{$\begin{array}{c}\text { NEITHER AGREE } \\
\text { NOR DISAGREE }\end{array}$} \\
\hline $\mathbf{1 8}$ & $\begin{array}{c}\text { I worry about my writing ability which } \\
\text { prevents me from starting to write. }\end{array}$ & $28 \%$ & $23 \%$ & $48 \%$ & $59 \%$ & $24 \%$ & $18 \%$ \\
\hline $\mathbf{2 1}$ & Having my writing evaluated is scary. & $41 \%$ & $42 \%$ & $34 \%$ & $46 \%$ & $25 \%$ & $12 \%$ \\
\hline $\mathbf{2 2}$ & I expect good grades on academic papers. & $57 \%$ & $58 \%$ & $6 \%$ & $8 \%$ & $37 \%$ & $44 \%$ \\
\hline
\end{tabular}

$(N=91)$

Table 2. Writer self-efficacy 
In the post- survey, more respondents disagreed with the statement "I worry about my writing ability which prevents me from starting to write" (Q18). There was also a drop in the number of students who agreed with the statement.

The reduction in student anxiety about being evaluated is considerable, as indicated by the 12 percentage points increase in responses disagreeing with the statement "Having my writing evaluated is scary" (Q21). In Question 22 there is little change in students' positive expectations about good grades on academic papers. There is also an overall reduction from pre- to post- surveys in the number of students who reported that they neither disagreed nor agreed with the statements, except for Question 22. These results from the surveys will be discussed along with the results from the reflection which are presented in the next section.

\subsubsection{Survey analysis by theme: Writing proficiency}

Students' perceptions of writing proficiency relate to writer autonomy and selfefficacy (Galbraith, 2009; Oxford, 2015). Analysis of the pre- and post-course responses indicate an overall improvement in students' self-assessment of writing proficiency. Students reporting good or very good writing skills rose by a total of 15 percentage points at the end of the course. At the other end of the scale, there was an increase of 2 percentage points in the number of students who reported poorer writing. The post-survey decrease of 17 percentage points in the proportion of students who reported neither-good-nor-poor writing also indicates improved self-evaluation of their writing. Clearly, students perceived that their writing skills have improved, especially in writing research papers. These are seen in Table 3.

\begin{tabular}{|l|c|c|c|}
\hline & $\begin{array}{c}\text { Pre- } \\
\text { SURVEY }\end{array}$ & $\begin{array}{c}\text { PoST- } \\
\text { SURVEY }\end{array}$ & CHANGE \\
\hline 1. Very poor* & 0 & 0 & \\
\hline 2. Poor & $12 \%$ & $14 \%$ & $+2 \%$ \\
\hline 3. Neither good nor poor & $31 \%$ & $14 \%$ & $-17 \%$ \\
\hline 4. Good & $43 \%$ & $46 \%$ & $+3 \%$ \\
\hline 5. Very good & $14 \%$ & $26 \%$ & $+12 \%$ \\
\hline Total & $\mathbf{1 0 0 \%}$ & $\mathbf{1 0 0} \%$ & \\
\hline & *No one marked very poor (N=91) \\
\hline
\end{tabular}

Table 3. Students' views of their writing skills

\subsection{Reflections}

The reflection on the course encouraged metacognitive awareness about thesisdriven writing and also served as a source of data related to changes in writer self- 
efficacy and autonomy. Below, students' reflections on thesis-driven writing are presented.

\subsubsection{Theme \#1: Thesis-driven writing}

Reflection on the purpose of a thesis statement was the fourth in a series of six reflection text boxes embedded into the course text. The 111 responses on thesisdriven writing were 1-2 paragraphs long on average.

An interpretive analysis of students' responses using a Grounded Theory approach (Creswell, 2013; Smith et al., 2009) revealed six general themes. They were:

1. The effects of course instruction on thesis-driven writing

2. Writing in the humanities vs. other types of writing including at secondary school

3. Writing in other languages vs. writing in English

4. Responses that do not address the question/prompt

5. Description of what they do in general while writing - not addressing the question about thesis-driven writing

6. Responses that said that they always wrote guided by a thesis.

The first four themes are addressed below. The last two themes (\#5 and \#6) will be discussed briefly as they seem to represent the views of native-English speakers and are beyond the scope of this study. Students' commentaries include observations on the positive effects of the textbook in helping them to understand the structure of academic papers, and to focus their arguments. Representative comments are presented thematically below. Students' fluency in English narrative is reflected in verbatim quotes used as examples.

Students indicated an awareness of the purpose and value of a thesis statement in academic writing. The majority of students, or $68 \%$, reported that their writing became easier after adopting a thesis to guide them, often with reference to specific assignments or passages in the textbook, as exemplified in the quotes below:

When I first started at the University of Iceland, I truly had no idea what a thesis meant and I wasn't sure how to corporate [incorporate] a working thesis into the paper that I was writing. However, as time went by I learned that the thesis is the most important part of the essay because it tells the reader what it is I am looking to explain and then the supported evidences and explanations are to be found in the essay itself. (Student \#18)

Another student described his experiences in this manner: 
I started the paper without really knowing the thesis statement and what exactly I was going to write about. The problem with that was that the main idea of the paper was always changing. (Student \#43)

Another student simply responded this way:

It ended in a complete mess. (Student \#35)

Clearly these three students are advanced users of English as their language demonstrates, yet they seem unfamiliar with having their writing guided by a thesis prior to this course.

\subsubsection{Theme \#2: Writing in the humanities vs. previous writing experience and instruction}

Five students mentioned specifically that requirements for writing in the humanities differed from prior expectations. The following quote is representative of comments suggesting that the secondary-school EFL instruction students receive is inadequate preparation for university writing:

While I was in college (Upper Secondary School) I took all the English courses that were available. What I found really frustrating while starting at the University of Iceland was how I did not have any good background in the development and the process of writing a paper and I blame my college. (Student \#99)

Such comments support findings of other studies on students' experiences in high school EFL classes (e.g. Jeeves, 2013).

Another writer described the frustration of trying to write a humanities paper without understanding the structure and purpose of an academic paper:

I once wrote a paper on $19^{\text {th }}$ century London and Victorian era social structure, topics I became very interested in at the time but hardly knew much about. I think it is safe to say that it is one of the worst texts I have written to date. The thesis was weak and the topic(s) much too broad. I have since learned that a more narrowed and stronger thesis makes the whole writing process a lot easier and you can find your way to the end more quickly. (Student \#31)

The quotes above suggest that at least some students enter EMI programs after several years of EFL study seemingly unaware of the basic feature of English writing in the humanities, namely thesis-driven writing. 


\subsubsection{Theme \#3: Academic writing in English vs. other languages}

English academic writing poses a challenge for EMI students whose previous academic training has been in a different language (Arnbjörnsdóttir \& Ingvarsdóttir, 2017; Dimova et al., 2015; Hellekjær, 2009). Reflections related to this theme included 17 comparisons of academic writing in English with other languages. Students made specific references to the fact that thesis-driven writing was not characteristic of other languages with which they were familiar.

Some comments suggest that students with more limited proficiency in academic English relied on course prompts and guidelines rather than their own skills. For example:

As this kind of method to write essays is not familiar for me in any way, since where I have studied before arriving to Iceland, we learned in other ways how to write and they were not precise but more like guidelines, so we were only told to have a good introduction and a good conclusion and that the body paragraph should be clear and organized, and of course, the vocabulary and syntax should be according to the type of essay we were supposed to write. (Student \#64)

Other statements reflect a change in student's awareness of the role of a thesis in English compared to other languages:

Writing a paper without a working thesis is challenging. I have written many papers in [language] without a thesis statement. (Student \#70)

Some students' observations suggest that they were less aware of cultural differences in discourse structures, which may have led them question the importance of the thesis statement based on their prior experiences of writing in another language. Take Student \#33 for example:

As a matter of fact, I have never write a paper without really knowing what I was going to write about. However, I find really difficult to work the thesis out first and then start writing. I tend to depart not from a thesis, but from a question, which is answer during the process of writing the essay, and the thesis is usually the answer to that question. (Student \#33)

The students whose reflections focused on language differences appear to demonstrate lower levels of language proficiency than those students whose comments focused on thesis-driven writing and writing in the humanities. In addition, responses in this thematic category exhibited limited awareness of cultural variations in text structures. This raises the question of whether instruction in their home universities addressed this essential component of academic writing in English. 


\subsubsection{Theme \#4: Low proficiency writers who do not seem to respond to the prompt}

Developing writer self-efficacy and autonomy in L2 is linked to language proficiency and comprehension of content (Galbraith, 2009). Students who did not address the topic of the prompt may not have the language proficiency necessary to understand, analyze, and respond to the topic of the prompt. Below are examples of representative responses from the fourteen students with tangential responses. They are presented as they were written by the students:

When I started to write a paper without really knowing then I will try to know it first. Furthermore, I will write down what information I already known, and try to consider other side. (Student \#78)

I searched and read many related articles to find some clues or some interesting points to write. And found the structure and logic to organize the whole paper. (Student \#110)

I understand how it will go when I don't know what I am writing. Making structure of my paper always helped me. It tells me where am I in my paper. (Student \#86)

The fourteen students who did not seem to understand the question and whose responses seemed to be out of context were all exchange students inappropriately assigned to this class as it was above their language proficiency level. Their comments exhibit grammatical and language usage features characteristic of texts written by students with lower English proficiency than was required for this course.

\subsubsection{Theme \#5: Fluent writers with tangential responses}

A further fourteen students described generally how they approached writing assignments without addressing the question directly. The responses suggest a rather "shallow" view of academic writing or a lack of awareness of thesis-driven writing. Their focus was on their own feelings, state of mind, or confusion about what topic to write about. Their writing was fluent, suggesting that they understood the prompt but chose not to respond to it for some reason. Many described going for walks, watching movies, reading, and exercising before writing. 


\subsubsection{Theme \#6: Students who reported that they were always guided by a thesis when writing}

Eleven students said that their writing had always been guided by a thesis. These participants are native speakers of English or bilingual. Obviously, the study and approach to writing is not aimed at these 11 students nor the 14 students identified under theme \#5 above. The responses of these 25 students, although possibly illuminating the views of native- or near native-English writers on academic writing, are not included in the following discussion.

\section{DISCUSSION}

The survey results demonstrate an increase in writer autonomy and students' perception of their ability to execute the writing task in humanities assignments. The change in students' perceptions of their ability to write a research paper without assistance suggests greater sense of control over their own writing after the course. Respondents who agreed or strongly agreed with the statement "I can write a research paper without any help or instruction" increased by 13 percentage points.

The sizable increase of 24 percentage points in the proportion of students who agreed with Statement 4 "I am familiar with the components of a research paper" demonstrates growth in the psychological dimension (Oxford, 2015) of autonomy. The cognitive knowledge of the components and structure of the research paper seems to have empowered the student writers to apply strategic knowledge related to organization, goal-setting, and planning relevant to the genre (Hyland, 2007).

Students' reflections on thesis-driven writing support the findings of increased writer autonomy. The comments suggest that understanding the features of, and strategies for, thesis-driven writing gives students a greater sense of agency and control over their writing. The percentage of students (67.6\%) who observed that adopting a thesis made their writing easier is noteworthy.

The lack of perceived improvement in students' ability to revise their own papers is a concern. Revision strategies were integrated progressively throughout the course. Because writing was so heavily scaffolded in the early part of the course, opportunities for "mistakes" were minimized and there was less focus on revision. Revision strategies were emphasized more explicitly in the later chapters. This suggests that students need more explicit instruction in revision strategies early in the semester.

Analysis of the data from pre- and post- surveys and reflections indicate an overall improvement in students' self-efficacy for writing after the course. Pre- and post- survey comparisons show a reduction in anxiety over starting a writing assignment as well as having their writing evaluated. The reflections suggest more 
strongly than the survey data that the majority of the students perceived an improvement in their ability to write thesis-driven texts. Two-thirds of the students described improvements in writing as a result of the course. Others noted that taking the course and using the new text and approach to the course improved their academic writing.

The lowered anxiety levels, combined with students' perceptions of improved writing proficiency, suggest improved self-efficacy for writing. This increased confidence and belief in their ability to accomplish the task may exert a positive influence on their motivation and may predict improved writing performance (Pajares, 2003) This is an important change and suggests that specially designed instruction that targets the needs of EMI learners may reduce the stress students report when studying in English (Arnbjörnsdóttir \& Ingvarsdóttir, 2015; Hellekjær, 2005, 2009; Pecorari et al., 2011; Pecorari et al., 2012). Writer autonomy overlaps with writer self-efficacy because the ability to plan and execute a writing task influences beliefs, feelings, and motivation. Students' reports of increased confidence in their ability to plan, organize, and write academic text when guided by a thesis add further support to findings of growth of writer self-efficacy.

Lower English proficiency students, as indicated in their writing, reported modest improvement in their written reflections. The AAAW textbook and program approach were designed to meet the specific needs of EMI students with advanced levels of proficiency who lack functional skills in the academic genres (Arnbjörnsdóttir \& Ingvarsdóttir, 2015; Hellekjær, 2005, 2009; Pecorari et al., 2011; Pecorari et al., 2012). Reflection comments of lower proficiency students suggest that they did not fully understand the concept of thesis-driven writing. These findings lend credibility to the premise that the needs of advanced English speakers studying through EMI are distinct from the needs of EFL students who are still developing English language skills. EFL students are not yet at the advanced level of English that allows them to engage in the deeper cognitive processes associated with competent L1 writers (Lavelle \& Zuecherer, 2001; Lavelle \& Guarino, 2003). Background data indicate that approximately $10 \%$ of the participants in the surveys were exchange students from other countries. There were also a small number of L2 students enrolled in the course under the erroneous belief that it would improve their EFL accuracy skills.

Understanding academic genres was an important aim of the program and textbook. The course scaffolded instruction from the essay, through a case study, and culminated in a research paper. Survey prompts posed questions related to writing essays as well as research papers. Both survey data and reflection comments indicated that students improved their understanding of the components of the research paper. The increase of 24 percentage points was one of the largest in the survey. In contrast, there was a minimal increase in students' response to the statement "I do well on tests requiring essay answers." It was an unexpected finding since essay writing was an important part of the curriculum. 
One explanation may be that students perceived timed essay questions as a separate genre to the process-oriented essay in the course text. The small increase in transfer to tests using essay questions may be a consequence of the timing of the survey, which was administered at the end of an intensive writing course but before the general exam period. At the time of the survey, students may not have had the opportunity to write essays independent of the writing course as part of their end of term evaluations in other content courses. This seems to suggest that the independent production of the targeted task is a prerequisite for autonomy.

Students' responses to the reflections on thesis-driven writing in the humanities demonstrate metacognitive awareness of the purpose, the components, and the strategies associated with academic writing. Students also articulated changes in academic writing before and after the program. The growth in metacognitive awareness may contribute to an unexpected finding: a pre- to postcourse decrease in survey responses indicated neither agreement nor disagreement on six of the seven questions related to writer autonomy and selfefficacy. This finding may reflect students' increased metacognitive awareness of the expectations of academic writing as well as of their own strengths and weaknesses as writers.

\section{CONCLUSIONS}

Current thinking in second language writing underscores the complex nature of differences among second language writers (Doolan, 2017). While EMI students are second language writers, the challenges they face are content-based, mainly involving rhetorical functions in academic writing rather than second language proficiency. Neither traditional form-focused ESL writing texts nor English composition texts for native speakers address their needs.

Because the challenges of EMI students are often unacknowledged, or not understood, they are not afforded the level of academic support that ESL or nativeEnglish speakers receive. The teaching approach described here is an effort to provide support specifically designed to meet the ESAP needs of this target group. The approach and accompanying textbook have been in development for over six years. The study reported here is part of an ongoing mixed-method approach to evaluation conducted at the end of each semester. Evaluations continue to inform ongoing revisions and updates to the book. Results indicate that the program has been successful in meeting the needs of EMI writing instructors and students.

However, the study has some limitations: most of the participants were linguistics or literature students; the small number of participants in other disciplines precludes generalizing findings across other disciplines. The limited time frame of the study also made it difficult to measure whether the skills transferred to other genres since participants need time to put their skills to use in 
other courses. Finally, this study does not measure actual improvement in student writing. These data are available and will be included in future research.

Universities that aspire to raise their international profile through EMI programs have lagged in providing writing support to the students they recruit to these programs (Dearden, 2015). Dearden reports a dearth of teaching materials and instructional approaches for this population. The program presented here is an effort to provide appropriate academic support to this newly defined student population. By targeting autonomy in the production of key components common to most academic writing genres, the Art and Architecture of Academic Writing seeks to create a "gateway to the more elaborate genres in which they may be recontextualized" (Gardner \& Nesi, 2013: 47). Much like an artist who must master basic principles of his/her medium as a foundation for personal artistic expression, mastery of key writing structures serves as a foundation for expanding writing competency to other genres and provides a solid footing for expressing the writer's academic voice. Because university programs may not have the resources to provide genre-specific writing instruction for EMI learners across multiple disciplines, an approach that concentrates on a few crucial writing features provides an important gateway to more complex genre-specific writing required of EMI students in the humanities.

[Paper submitted 30 Jun 2017]

[Revised version received 23 Sep 2017]

[Revised version accepted for publication 24 Oct 2017]

\section{References}

Archer, A., \& Hughes, C. (2011). Explicit instruction: Effective and efficient teaching. New York: Guilford Press.

Arnbjörnsdóttir, B., \& Ingvarsdóttir, H. (2010). Coping with English at university: Students' beliefs. Ráðstefnurit Netlu - Menntakvika Netla - Veftímarit um uppeldi og menntun og Menntavísindasvið Háskóla Íslands.

Retrieved from http://netla.hi.is/menntakvika2010/008.pdf

Arnbjörnsdóttir, B., \& Ingvarsdóttir, H. (2015). Simultaneous parallel code use: Using English in university studies in Iceland. In A. H. Fabricius, \& B. Preisler (Eds.), Transcultural interaction and linguistic diversity in higher education: The student experience (pp. 142-160). London: Palgrave.

Arnbjörnsdóttir, B., \& Ingvarsdóttir, H. (Eds.) (2017). Language development across the lifespan: The impact of English on education in Iceland. Berlin: Springer.

Bandura, A. (1977). Self-efficacy: Toward a unifying theory of behavioral change. Psychological Review, 84, 191-215.

Brown, J. S., Collins, A., \& Duguid, P. (1989). Situated cognition and the culture of learning. Educational Researcher, 18(1), 32-42.

Coleman, J. A. (2006). English-medium teaching in European higher education. Language Teaching, 39, 1-14. 
Creswell, J. W. (2013). Qualitative inquiry and research design: Choosing among five approaches (3rd ed.). Thousand Oaks, CA: Sage.

Deane, P., Odendahl, N., Quinlan, T., Fowles, M., Welsh, C., \& Bivens-Tatum, J. (2008). Cognitive models of writing: Writing proficiency as a complex integrated skill (ETS Research Report No. RR-08-55). Princeton, NJ: Educational Testing Service. doi: 10.1002/j.23338504.2008.tb02141.x

Dearden, J. (2015). English as a medium of instruction - A growing global phenomenon. London: British Council. Retrieved from https://www.britishcouncil.org/sites/default/files/e484_emi__ccover_option_3_final_web.pdf

Dimova, S., Hultgren, A. K., \& Jensen, C. (2015). English-medium instruction in European higher education: English in Europe, Vol. 3. Amsterdam: DeGruyter.

Doolan, S. M. (2017). Comparing patterns of error in Generation 1.5, L1, and L2 first-year composition writing. Journal of Second Language Writing, 35, 1-17.

Flowerdew, J. (2016). English for specific academic purposes (ESAP) writing: Making the case. Writing \& Pedagogy, 8(1), 5-32. doi: 10.1558/wap.v8i1.30051

Galbraith, D. (2009). Cognitive models of writing. German as a Foreign Language Journal, 2(3), 7-22.

Gardner, S., \& Nesi, H. (2013). A classification of genre families in university student writing. Applied Linguistics, 34(1), 25-52.

Graham, S., \& Perin, D. (2007). A meta-analysis of writing instruction for adolescent students. Journal of Educational Psychology, 99, 445-476. http://dx.doi.org/10.1037/00220663.99.3.445

Graham, S., Harris, K. R., \& McKeown, D. (2013). The writing of students with learning disabilities, meta-analysis of self-regulated strategy development writing intervention studies, and future directions. In H. L. Swanson, K. R. Harris, \& S. Graham (Eds.), Handbook of learning disabilities (2nd ed.) (pp. 405-438). New York, NY: The Guilford Press.

Hall, H., Magee, C., \& Clapp, T. (2016). 4-step model to approach case-based learning in the classroom. MPAEA Journal of Adult Education, 45(2), 24-27.

Hellekjær, G. O. (2005). The acid test: Does upper secondary EFL instruction effectively prepare Norwegian students for the reading of English textbooks at colleges and universities? (Unpublished doctoral dissertation). University of Oslo, Oslo, Norway.

Hellekjær, G. O. (2008). A case for improved reading instruction for academic English reading proficiency. Acta Didactica Norge, 2(1), 198-222.

Hellekjær, G. 0. (2009). Academic English reading proficiency at the university level: A Norwegian case study. Reading in a Foreign Language, 21(2), 198-222.

Hellekjær, G. O., \& Westergaard, M. R. (2003). An exploratory survey of content learning through English at Nordic universities. In C. van Leeuwen, \& R. Wilkinson (Eds.), Multilingual approaches in university education (pp. 65-80). Nijmegen: Valkhof Pers.

Holec, H. (1981). Autonomy and foreign language learning. Oxford: Pergamon Press.

Hultgren, A. K., Gregersen F., \& Thøgersen, J. (2014). English in Nordic universities: Ideologies and practices. Amsterdam: John Benjamins.

Hyland, K. (2007). Genre pedagogy: Language, literacy and L2 writing instruction. Journal of Second Language Writing, 16, 148-164.

Jeeves, A. (2013). Relevance and the L2 self in the context of Icelandic secondary school learners: Learner views (Unpublished doctoral dissertation). University of Iceland, Reykjavík, Iceland. 
Lavelle, E., \& Zuercher, N. (2001). The writing approaches of university students. Higher Education, 42(3), 373-391.

Lavelle, E., \& Guarino, A. J. (2003). A multidimensional approach to understanding college writing processes. Educational Psychology, 23(3), 295-305.

Ljösland, R. (2008). Lingua franca, prestisjespråk og forestilt fellesskap: om engelsk som akademisk språk i Norge: et kasusstudium i bred kontekst [Lingua franca, prestige language and imagined communities: English as an academic language in Norway: A case study in a broad context]. Trondheim: Norges teknisknaturvitenskapelige universitet.

MacArthur, C. A., Philippakos, Z. A., \& Ianetta, M. (2015). Self-regulated strategy instruction in college developmental writing. Journal of Educational Psychology, 107(3), 855-867. http://dx.doi.org/10.1037/edu0000011

O'Malley, J. M., \& Chamot, A. U. (1990). Learning strategies in second language acquisition. Cambridge: Cambridge University Press. http://dx.doi.org/10.1017/CB09781139524490

Oxford, R. L. (1990). Language learning strategies: What every teacher should know. Boston: Heinle \& Heinle.

Oxford, R. L. (2003). Toward a more systematic model of L2 learner autonomy. In D. Palfreyman, \& R. C. Smith (Eds.), Learner autonomy across cultures: Language education perspectives (pp. 75-92). Basingstoke, Hampshire \& New York, NY: Palgrave Macmillan. http://dx.doi.org/10.1057/9780230504684_5

Oxford, R. L. (2015). Expanded perspectives on autonomous learners. Innovation in Language Learning and Teaching, 9(1), 58-71. doi: 10.1080/17501229.2014.995765

Pajares, F. (2003). Self-efficacy beliefs, motivation, and achievement in writing: A review of the literature. Reading \& Writing Quarterly, 19, 139-158.

Pecorari, D., Shaw, P., Irvine, A., \& Malmström, H. (2011). English textbooks in parallel language tertiary education. TESOL Quarterly, 45, 313-333.

Pecorari, D., Shaw, P., Irvine, A., Malmström, H., \& Mežek, Š. (2012). Reading in tertiary education: Undergraduate student practices and attitudes. Quality in Higher Education, 18, 235-256.

Pilkinton-Pihko, D. (2010). English as lingua franca lecturers' self-perceptions of their language use. Helsinki English Studies, 6, 58-74.

Segev-Miller, R. (2004). Writing from sources: The effects of explicit instruction on college students' processes and products. Educational Studies in Language and Literature, 4(1), 5-33. doi: 10.1023/B:ESLL.0000033847.00732.af

Smith, J. A., Flowers, P., \& Larkin, M. (2009). Interpretative phenomenological analysis: Theory, method and research. London: Sage.

Swerts, S., \& Westbrook, P. (2013). Preparing students and lecturers for English medium instruction at the University of Copenhagen. Sprogforum, 56, 71-78.

Vinke, A. A., Snippe, J., \& Jochems, W. (1998). English medium content courses in nonEnglish higher education: A study of lecturer experiences and teaching behaviours. Teaching in Higher Education, 3, 383-394.

Wächter, B., \& Maiworm, F. (Eds.) (2015). English-taught programmes in European higher education: The state of play in 2014. (ACA Papers on international cooperation in education). Bonn: Lemmens Medien GmbH. Retrieved from http://www.acasecretariat.be/fileadmin/aca_docs/images/members/ACA-2015_English_Taught.pdf

Wilkinson, R. (2005, September). The impact of language on teaching content: Views from the content teacher. Bi- and multilingual universities - Challenges and future prospects conference. Helsinki, Finland. Retrieved from http://www.palmenia.helsinki.fi/congress/bilingual2005/presentations/wilkinson.pdf 
BIRNA ARNBJÖRNSDÓTTIR is Professor of Second Language Studies at the University of Iceland and Associate Dean of the Faculty of Languages and Cultures. She directs an ongoing research project on the changing status of English in Iceland and its functions in education. She has been involved in refocusing English Education programs to meet students' changing educational needs.

PATRICIA PRINZ specializes in Academic Language and Literacy development in ESL/EFL for K-12 through higher education. She has more than twenty years of experience developing curricula and teaching writing to undergraduate and graduate first and second language speakers. She has facilitated professional development for English teachers in Europe, Southeast Asia, South America, and the Middle East. Dr. Prinz was awarded Fulbright Specialist Grants to consult with English departments at universities in Indonesia and Iceland. She is Associate Professor of Literacy and Multilingual Studies at Mercy College in New York City where she works with TESOL educators.

\section{Appendix}

Academic Writing Survey

University of Iceland

School of Humanities

Department of Language and Cultures

Pre- and post-course survey - questions

Dear students: Thank you for participating in this survey. We are introducing a new writing program in this course. The textbook, The Art and Architecture of Academic Writing, is written for advanced users of English as a foreign language. In order to provide students with the best possible writing program, we would really

A. Background Questions appreciate hearing what you think about the book.

1. What is your main area of study?

2. What is your year of birth?

3. What is your sex?

4. How many years have you been at university?

5. Have you lived in an English speaking country after you turned 5 years old, and if so, for how long?

6. What was your average grade in English in secondary school?

7. Please estimate how many of your subjects (other than English) were taught in English in secondary school.

8. Which levels in English did you complete in secondary school?

B. English Proficiency

9. How good is your spoken English?

10. How good is your reading comprehension of English academic texts?

11. How good is your understanding of spoken English?

12. How would you rate your English writing skills?

C. Previous English Education

13. Can you estimate how many papers you have written in English before you started this course?

14. How much of the overall English instruction in secondary school was spent on writing instruction?

15. It is important to be able to write English well

16. Which of the following writing activities have you practiced prior to taking this course? 
Mark as appropriate:

Prewriting

Free writing

Outlining

Using composing strategies

Writing thesis statement

Writing introductions

Writing body paragraphs

Writing conclusions

D. Autonomy

17. I can write a research paper without any help or instructions

18. I worry so much about my writing that it prevents me from getting started

19. Writing an essay or paper is always a slow process

20. Studying grammar and punctuation would greatly improve my writing

21. Having my writing evaluated scares me

22. I expect good grades on essays or papers

23. I need special encouragement to do my best at writing

24. I do well on essay tests

25. My writing expresses what I really think

26. I find the comments of a partner or small group helpful when I revise a paper

27. I often do writing assignments at the last minute and still get a good grade

28. I cannot revise my own writing because I cannot see my mistakes

29. I am able to structure my writing to complete papers in approximately the length or number of words specified by the instructor

30. I am familiar with the components of a research paper

31. The following components of writing are easy for me. Mark as many as appropriate.

Finding things to say

Starting the paper

Coming up with a good thesis statement

Finding the right language to express my views

Reporting what I have read

Writing good conclusions

32. The following components of writing are difficult for me. Mark as many as appropriate.

Finding things to say

Starting the paper

Coming up with a good thesis statement

Finding the right language to express my views

Reporting what I have read

Writing good conclusions

33. I can write in my own voice

34. I can produce clear, concise and well organized text

35 . I can write academic text

36. I recognize the difference between formal and informal language 